\title{
COMPARATIVE ANALYSIS OF THE LEGISLATIVE, TECHNOLOGICAL AND OPERATIONAL ASPECTS IN THE FIELD OF CIVIL AVIATION SECURITY IN THE REGION BETWEEN EAST AND WEST
}

\author{
Gjorgji Alceski Ph.D, \\ Airport St. Paul the Apostle Ohrid, \\ TAV Macedonia Skopje \\ E-mail: Gjorgi.Alceski@tav.aero \\ Tomislav Tuntev Ph.D \\ Assembly of the Republic of Macedonia, Skopje \\ E-mail: t.tuntev@yahoo.com
}

\section{Abstract}

The events that follow our modern society in terms of endangering the safety of civil aviation have an undoubtedly and direct impact on the development of specific legislative, technological and operational segments in the area of aviation safety, to provide an effective protection against the acts of unlawful interference, without disruption of the safety, regularity and efficiency of the flights.

The rapid rise of the civil aviation requires a fast safety development, in a way the common denominator of all undertaken activities and measures is the creation of perspectives and conditions for the highest possible level of aviation safety. It does require the development of new, modern and sustainable forms of security, which mean a contemporary approach to continuous upgrading and improvement of the theoretical and practical solutions of dealing with the threats, and creating conditions for the applicability of modern technological achievements in the countries of the region.

Primary goal of the paper is to make a comparative analysis of the legislative, technological and operational segments in the field of civil aviation security in the East 


\section{Seccurity}

and West countries with those in the Balkans; a secondary objective is to consider the conditions and feasibilities for balanced development and joint efforts for an efficient cooperation of the East and West countries with those in the Balkans, as an integral part of the common global security platform. Based on established international standards, recommendations and practices, the necessity should be confirmed of immediate implementation of the advanced safety technologies in the state security systems in the region, as a mutual interest of the entire international community.

Aviation security should be an example for arrangement of the security policies in all other areas where security is still not regulated sufficiently. This is especially referring to so-called "Critical infrastructure", in order to establish the basic framework for defining and regulating a very important and significant segment which is part of the safety system of each country.

Key words: aviation, safety, security, critical infrastructure, acts of unlawful interference

\section{The importance of the regulation of the civil aviation security}

The civil aviation, observed as a global transport system, in terms of functional structure, may be conditionally divided into three subsystems: aerodromes (airports), airlines (aircrafts) and air traffic control (ATMS - air traffic management system). Each of these subsystems consists of several functional elements: system user, infrastructure, controls, managing structures, technological procedures, technical and human resources, law regulation, international legislation, etc ${ }^{139}$. A potential direct negative impact on the safety of any of these aviation subsystems could result with serious consequences for the airline industry, which has a very significant and important role in the national economy, as well as in the national security of any state. The implementation of modern security systems and procedures, relating to the need for establishing an optimum level of safety, becomes a top priority of civil aviation. The complexity of the issues that treats the civil aviation, seen through the unquestionable

139 T. Tuntev - Aerodromes - Faculty of Technical Sciences Bitola 2005 


\section{Security}

need for an adequate protection, is a very big challenge, to which in the future should be given more attention.

The security in the area of the civil aviation, through the implementation of specific regulations, standards, recommendations, practices, advanced systems and procedures, has a function:

- to protect the safety of passengers, crew, aircraft, ground staff, greeters and meeters or any other person and object, in matters of providing an effective protection against the acts of unlawful interference, and

- to ensure readiness for rapid response against increased security threats ${ }^{140}$.

The civil aviation security (AVSEC) involves a combination of measures, human and material resources, with a main goal to protect people and objects from acts of unlawful interference. The fundamental principles of the AVSEC philosophy are:

- the civil aviation takes place in a safe and secured environment, free from unlawful interference;

- the states develop and implement legislation and procedures, necessary to ensure a safe and secured environment;

- the security measures implemented by the states, in order to protect the civil aviation against acts of unlawful interference, must be in accordance with the standards required and recommended practices contained in Annex 17 of the Convention on International Civil Aviation, also known as the Chicago Convention, of the International Civil Aviation Organization (ICAO); and

- accordance with their national regulation, the states will prosecute any person who will attempt or commit an act of unlawful interference and/or extradite such a person(s) in state(s) that are willing to prosecute such offenders ${ }^{141}$.

Having all that in mind, as well as the need to secure the effective protection of the civil aviation regardless of the level of development of the state, the Balkan states have an obligation to implement and apply the required international standards and recommended practices related to AVSEC. To achieve an unified level of the aviation safety, each state builds their one aviation safety platform through comprehensive policy of applying a relevant legislation, that must be implementted by all entities involved in any AVSEC structure.

\footnotetext{
140 ICAO - Annex 17 International Standards and Recommended practices November 2016

${ }^{141}$ ICAO - aviation security training package instructors - trainee reference book 2012
} 
Typical acts of unlawful interference in the civil aviation all over the world

The frequent events of the terrorist attacks all over the world, especially those in the area of civil aviation, show that the terrorism doesn't recognize the state borders or social and political systems. Neither the countries of the West nor East nor does the Balkan countries are not spared from such terrorist acts. The recent events and developments have set a new chapter in the security sciences, especially in the segments related to the airline industry, where threats and dangers grow in proportion to the fast development of all civil aviation segments.

Usually, the effects and damages, caused to civil aviation of such events, are devastating, with loss of human lives and enormous material losses. The omissions and deficiencies made by the security services and the readiness of saboteurs to manipulate the security systems at airports, smuggling firearms or explosive devices, increase the risk for terror atacks. The terrorism is actually the biggest danger and the most common cause for endangering the aviation safety, which dates back to the very beginnings of the air transport development. ${ }^{142}$ Throughout the history of the civil aviation there are frequent examples of terrorist attacks and threats. They vary according to the desired objectives, as well as to the means and methods used in those attacks.

The unfortunate and tragic events in the area of the civil aviation always attract the attention of many people in public, mostly through the public media. Everybody, as a potential passenger, wants to be well informed and aware of the level and sustainability of the aviation safety and security. The feeling of being safe and secured during the flight or staying at the airports is one of the most important and strongest feelings for every passenger, making the decision to travel.

There are many unfortunate events throughout the history of the modern civil aviation, but but below are listed just a few of the most characteristic of them:

- On December 21, 1988, Pan Am Flight 103 exploded 31,000 feet over Lockerbie, Scotland, 38 minutes after takeoff from London. Two hundred fifty-nine people on board the New York-bound Boeing 747 were killed, along with 11 people on the ground. Afterward, United States and British investigators found fragments of a

${ }^{142}$ Protection for critical infrastructure: Oliver Bakreski, Tanja Milosevska, Cjorgji Alceski Skopje 2017. 


\section{Seccurity}

circuit board and a timer, and ruled that a bomb, not mechanical failure, caused the explosion $^{143}$;

- On the morning of 11 September 2001, 19 hijackers took control of four commercial passenger jets flying out of airports on the east coast of the United States. Two of the aircraft were deliberately flown into the main two towers (the Twin Towers) of the World Trade Center in New York, with a third hitting the Pentagon in Virginia. The fourth plane never reached its intended target, crashing in Pennsylvania. It is believed that the passengers and crew overpowered the hijackers and took control of the plane. The total loss of life on 9/11 was nearly 3,000, including the 19 hijackers. It was the worst loss of life due to a terrorist incident on US soil.The days that followed saw a significant effect on world economic markets and international confidence. ${ }^{144}$

- On 24 January 2011, bomb attack at Moscow's Domodedovo airport has killed at least 35 people and injured more than 100 - many of them critically, officials say. Investigators say the explosion, which happened in the arrivals hall, was caused by a suicide bomber ${ }^{145}$. The Russian authorities confirmed that the attack was act of a suicide bomber, wearing a belt with a hidden explosive device under the clothes, which was detonated at the entrance of the baggage claim area in the international flights terminal at the airport;

- July 18 bombing of the bus carrying Israelis at Burgas airport on Bulgaria's Black Sea coast, the deadliest attack on Israelis abroad since 2004, also killed the Bulgarian bus driver and the bomber ${ }^{146}$. About 30 people were wounded. According to the reports from the Bulgarian media, the aim of the bomb attack were 150 Israeli tourists, landed from Tel Aviv just about half an hour before the explosion and entered into 3 buses at the landside, about to leave the airport to the Black Sea coast.

- On 31 October 2015, about 25 minutes after takeoff from the Sharm el Sheikh Airport in Egypt, the plane Airbus A321 of the airline Metrojet exploded as a result of planted homemade explosive device, killing all 224 passengers and crew. The most of the passengers (219) on that flight, from the famous Egyptian tourist resort to St. Petersburg in Russia, were from Russian nationality. The responsibility for the attack

\footnotetext{
${ }^{143}$ http://edition.cnn.com/2013/09/26/world/pan-am-flight-103-fast-facts/

${ }^{144} \mathrm{http}: / /$ www.bbc.co.uk/history/events/the_september_llth_terrorist_attacks

$145 \mathrm{http}: / /$ www.bbc.com/news/world-europe-12268662

${ }^{146}$ http://www.aljazeera.com/news/europe/2013/02/20132515350158754.html
} 


\section{Seccurity}

assumed the terrorist organization Islamic State (ISIS) ${ }^{147}$. According to the Russian officials, the improvised explosive device had a destructive power equivalent to $1 \mathrm{~kg}$ of TNT. On 18 November 2015 ISIS released photographs of the device for which it claimed was a bomb. Several employees at the airport, who were linked to ISIS, were suspected by the authorities for placing a bomb in the plane.

- On 23 December 2015 a bomb attack occurred at Sabiha Cökçen Airport in Istanbul, Turkey. The blast at Sabiha Gokcen, the city's second airport and located on its Asian side, occurred shortly after 2:00 a.m. (midnight GMT), local budget carrier Pegasus said, fatally wounding a cleaner on one of its planes. There was damage to five airplanes in total due to the impact of shrapne ${ }^{148}$.

- On 22 March 2016 in Brussels, Belgium, were three coordinated bombings two of them took place at Zaventem Airport, while third in the Maelbeek metro station in the center of Brussels. Bombing terrorist act at the airport was realized with two bomb explosions in the terminal building; after the search of the airport a third non activated explosive device was found, which was later destroyed. In these three attacks of suicide - bombers there were 32 casualties and more than 300 people were injured $^{149}$. The responsibility for these terrorist attacks in Brussels took the Islamic State of Iraq and the Levant (ISIL).

- On 28 June 2016 at Kemal Ataturk Airport in Istanbul, Turkey, there was organized terrorist attack that resulted in gunfire and bomb attacks in the airport terminal building. Several gunmen, armed with automatic weapons and explosive belts, attacked the passengers and visitors in the international terminal of the airport. 43 people have been killed and 239 injured in three blasts that rocked Istanbul's Ataturk airport, according to Turkish officials ${ }^{150}$.

With a very simple observation and analysis of the terrorist attacks that occurred in the area of civil aviation, whether it comes to airports or aircraft, can undoubtedly be seen the "attractiveness" to engage in unlawful acts on this kind of critical infrastructures. An obvious conclusion is that a number of terrorist strategies are aimed to vital facilities, which are of particular importance for each country. Such

\footnotetext{
${ }^{147}$ http://edition.cnn.com/2015/10/31/middleeast/egypt-plane-crash/

${ }^{148} \mathrm{http}: / /$ www.reuters.com/article/us-turkey-airport-blast-idUSKBNOU60DS20151223

${ }^{149}$ http://www.bbc.com/news/world-europe-35869985

${ }^{150} \mathrm{https} / / /$ www.rt.com/news/348735-explosion-atatukr-reports-injured/
} 


\section{Seccurity}

facilities usually have the highest level of protection and security, so the main intention of the organizers of such terrorist attacks is to cause a massive sense of fear, uncertainty and insecurity among the people, while causing distrust in the ability and willingness of the national authorities to cope with the dangers and threats. Hence, the goal of such terrorist attacks is to have the largest possible number of victims and to cause a great media effect. Therefore, a mandatory emphasis on safety and security is one of the dominant element in the mosaic of the organization of civil aviation. The events of recent years also have their direct impact on the projection and creation of specific security systems and procedures, that are constantly improve and upgrade to eliminate any possible shortcomings and lacks.

\section{Regulation of Civil Aviation Security in Europe}

In light of threats to civil aviation and existance of effective security system v.v. the complexity of the factors which lead to inefficiency of the security, there is a constant need of permanent improvement of the security measures, the conditions, the implementation of advanced systems and procedures. All this in order to build an effective security system through universal international standards in all aspects (organizational, regulatory, structural, substantive, technical, etc.).

The European approach, represented by ECAC (European Civil Aviation Conference), reflect main mission as promoting the continuing development of a safe, efficient and sustainable European air transport system ${ }^{151}$. Established in 1955 by several European countries, with headquarters in Paris, ECAC works through plenary sessions at the level of directors of the civil aviation authorities of the Member States, as well as at the level of Ministers of Transport. The main objectives of ECAC are: respect and care for the interests of the Member States in the field of civil aviation in Europe, finding solutions to solve their mutual problems and misunderstandings, cooperation with the bodies of the EC (European Commission) and ICAO, promotion of a common European AVSEC policy on the European sky, providing mutual cooperation in the development and implementation of common standards and procedures in the field

${ }^{151} \mathrm{https}$ // www.ecac-ceac.org/about-ecac 


\section{Secururity}

of civil aviation, etc ${ }^{152}$. It is comprised of 44 countries, almost all of Europe ${ }^{153}$. ECAC policy in the field of aviation safety have been developed and implemented in Doc. 30, which is developed in order to ensure equal access of all Member States and all other countries, whose airlines and airports should maintain an acceptable uniform level of safety measures, methods, principles, procedures, specifications, criteria, materials, data, etc. It is expected all Member States of ECAC to continue applying the SARPs (standards and recommended practicies) of ICAO Annex 17 and other relevant ICAO annexes, resolutions and manuals.

It should also be stressed that EU (European Union) has a significant role in creating a common European AVSEC policy, for all Member States and States Parties to the ECAA (European Common Aviation Area) Agreement, through the adoption of regulations and the implementation of standards in the field of security. The main objective is to achieve uniform standards in the security of civil aviation. Therefore, EU through regulations, as binding legal acts, sets guidelines regarding the regulation of civil aviation. First, in 2002 EU adopted its first common AVSEC rules, with detailed provisions on: access to sensitive areas of the airports and planes, screening and control of passengers and their baggage, security checks of cargo and mail, AVSEC training, screening and classification of weapons and other items that are prohibited to carry in aircraft, etc. Furthermore, in 2005 EC (European Commission) proposed amendments to the 2002 rules, introducing changes regarding the screening of passengers and baggage, security checks of aircraft, as well as recruitment or selection and training of AVSEC personnel. For the first time there were introduced rules securing the planes in terms of: access to the cockpit, dealing with inappropriate passengers with sky marshals on each flight, new ways to secure the aircraft, and more. The new rules were adopted in EU Regulation 300/2008, which included all ad hoc measures adopted in 2006, in reference with the threat of terrorist attacks in aircraft with liquid explosives.

Beside the EU Regulation 300/2008 as a basic document, below are presented the EU regulations that also treat the area of AVSEC:

- EU Regulation 185/2010: contains detailed measures for the implementation of common basic standards on AVSEC;

${ }^{152}$ T. Tuntev - Aerodromes - Faculty of Technical Sciences Bitola 2005

${ }^{153}$ http://www.caa.gov.mk/86/Chlenstvo_vo_megjunarodni_organizacii.html 


\section{Seccurity}

- EU Regulation 720/2011: amending EU Regulation 272/2009 with the common basic standards on AVSEC in relation to the screening of liquids, aerosols and gels at EU states airports;

- EU Regulation 1141/2011: amending EU Regulation 272/2009 with the common basic standards on AVSEC in relation of the use of scanners for security procedures at the airports in EU states;

- EU Regulation 1087/2011: amending EU Regulation 185/2010 with the common basic standards on AVSEC in relation with the systems for a detection of explosives;

- EU Regulation 1147/2011: amending EU Regulation 185/2010 with the common basic standards on AVSEC in relation with the use of security scanners at EU states airports;

- EU Regulation 711/2012: amending EU Regulation 185/2010 with the common basic standards on AVSEC in relations with the methods used for the control of persons at the airports who are not passengers and items they carry with them;

- EU Regulation 104/2013: amending EU Regulation 185/2010 regarding the screening of passengers and non-passengers by the equipment to ETD (explosives traces detection) combined with HMD (handy metal detector);

- EU Regulation 246/2013: amending EU Regulation 185/2010 regarding the screening of liquids, aerosols and gels at EU states airports in EU airports;

- EU Regulation 278/2014: amending EU Regulation 185/2010 regarding the clarification, harmonization and simplification of the procedures for ETD;

- EU Regulation 1998/2015: containing detailed measures for the implementation of common basic standards on AVSEC ${ }^{154}$.

\section{Regulation of Civil Aviation Security in USA}

The main specific characteristic in US is the fact that after the tragic events of 11 September 2001, the whole AVSEC system was transformed from decentralized to centralized, under the of ATSA (Aviation and Transport Security Act). As a result of it, the responsibility for AVSEC was transferred directly to the airport units of TSA (Transportation Security Administration) - sector within the US Department of

\footnotetext{
${ }^{154} \mathrm{https://www.iaa.ie/docs/default-source/publications/aviation-security-legislation/ec-}$ regulation-2015-1998.pdf?sfvrsn=4
} 


\section{Seccurity}

Homeland National Security. TSA has overall responsibility for all transportation modes of security within the US. The basic purpose of TSA is to secure all transportation systems in US, including aviation, to ensure free and safe movement of people and trade. Also, one of the most characteristic changes were adopted was giving the direct responsibility to the airport authorities for AVSEC, especially for the control of passengers, baggage and cargo. Also, some more obligations and powers were given to the airport authorities in several different areas of AVSEC.

After such a change, the US government, represented by the FAA (Federal Aviation Administration) remained with supervising and regulatory role. The FAA, as an agency of the Ministry of Transportation in US, has the authority to regulate and supervise all aspects of the civil aviation safety in US. This government body was formed in 1958, to regulate, develop and encourage research and other activities related to US aviation development in general. Also, TSA at the beginning was an agency within the Department of Transportation, but later was transferred within the US Department of Homeland National Security, that provided a major progress towards the fulfillment of the tasks set by the US Congress. Some specific actions were implemented by TSA in 2002, as: the recruitment and training of screening AVSEC staff, $100 \%$ screening of baggage at the airports, structural strengthening and firming the door of the cockpit, the introduction of advanced technology AVSEC equipment and devices, etc.

Besides this, in the US also exists another state body connected with the transportation safety: NTSB - National Transportation Safety Board. NTSB is an independent federal agency for investigations the transportation accidents. Since its creation in 1967, the mission of NTSB is to focus on determining the likely and possible causes of all serious incidents and accidents in area of transportation, and to formulate the recommendations aimed to upgrade the safety in all modes of transportation, including the aviation.

If we compare EU and US in terms of AVSEC measures and procedures, it's obvious that generally all individual acts and activities are adequately regulated and harmonized within the international organizations. In order to present the similarities or differences in implementation, we might mention the security measures related to the airports in the area of access control staff, security checks of the vehicles, access to controlled areas at airports, etc. In Europe, for example, all this is providing with a combination of different subjects: airport authority, police department and private 
security companies (outsourcing), while in US these activities remain a key responsibility of the airport authority. Further, the surveillance and supervision of the security activities in Europe are the responsibility of the CAA (Civil Aviation Agency), while in the United States this remains the responsibility of TSA. Referring the securing the aircraft, in EU as well as in US the protection and inspection of aircraft on the ground is usually the responsibility of the airline.

In Europe, the CAA usually are responsible to provide and comply the safety standards within the national legislation, while in US it's carried out by TSA. If we compare the procedures for security control of the passengers and cabin baggage, at the European airports it might be shared responsibility between the airport authority, the police and some private security companies, while in US passengers and baggage screening is solely the responsibility of the TSA. It should be mentioned that there are some differences also in terms of providing the security measures and procedures for cargo, mail, catering or duty free goods at the airports, as well as the security measures and procedures for general aviation, but the most important thing is that all those measures and procedures are strictly regulated and approved by relevant international institutions.

\section{Regulation of Civil Aviation Security in Russian Federation}

As well as EU and US, the regulation of civil AVSEC in Russian Federation also is a positive example of consistently compliance with the international SARPs, particular in the areas of appropriate legal framework, technical guidelines, procedures for licensing and certification and continuous supervision. Russian civil aviation is administered generally by five different bodies:

- Ministry of Transportation, which regulates the entire transportation system in the federation, including aviation;

- Federal Services for Supervision in the area of transportation, over observance and monitoring the implementation of the national legislation, including the civil aviation;

- Federal Aviation Agency, with authority on licensing activities related to aviation; 
- Aviation Committee, that coordinates all activities related to the use of national airspace and air traffic services and management, certifying the aircraft, airports and equipment, investigates aviation accidents, encourages the unification of different aviation rules, develops a coordinated policy in the field of aviation, coordinates the development and implementation of interstate scientific and technical programs, etc.;

- Aviation Registry, which is responsible for aircraft homologation and certification ${ }^{155}$.

In terms of ACVEC, it's important to mention that the Presidential Decree № 403 from March 2010, for establishing an integrated system of public transport safety, is a big step forward in the development and innovation in the field of the security; a program is developed for public traffic safety by implementing the new technologies and equipment for AVSEC, as well as the need for equipping the airports with modern security systems ${ }^{156}$.

In the AVSEC field, several federal bodies have competences and authority:

- Ministry of Transportation of the Russian Federation - a federal body of the state executive authority in area of transportation, defining the official state policy and normative-legal acts in the field of civil aviation;

- Federal Services for Supervision in the area of transportation - $a$ is a federal body of the state executive authority, carrying out its functions in control oversight legislation of the Russian Federation and international agreements in the field of civil aviation, as a special authorized body in the field of civil aviation;

- Federal Aviation Agency - also a federal body of the state executive authority, which perform its functions in securing the public services in the field of civil aviation ${ }^{157}$.

In the Report of the UN Counter-Terrorism Committee, connected with its visit of the Russian Federation regarding the safety of the civil aviation, it's stated that Russian Federation has established a highly effective aviation safety system and surveillance mechanism, which reflects the priorities set by the government in order to prevent illegal activities and acts of unlawful interference in area of civil aviation. The

\footnotetext{
155 http://digitool.library.mcgill.ca/webclient/StreamGate?folder_id=0\&dvs=1490967283946 457 $156 \mathrm{http} / /$ www.icao.int/Meetings/SIAS/Documents/New\%20Presentations/To\%20add\%20new/ Vladimir\%20Chertok\%20(1).pdf

${ }^{157}$ Ibid www.icao.int/Meetings/SIAS/Documents
} 


\section{Seccurity}

latest revisions to the ICAO USAP (Universal Security Audit Program) of the Russian Federation have been very positive. This program states that Russian Federation has established an appropriate national legislation and implemented all relevant international programs and policies to support the universal framework of aviation safety. Such a policy continues to impose strict quality controls throughout all areas of aviation security system and act quickly identified deficiencies and lacks to ensure compliance with all relevant national and international requirements ${ }^{158}$.

Generally, in terms of the AVSEC measures and procedures, there are some differences in Russian Federation with those in EU or US, but also there are many similarities; the legislation may be different in terms of structural organization, but it must be pointed that the Russian AVSEC measures and procedures are based on the principles of ICAO and other relevant international organizations and associations, which basically represent the main sources of legislations for security in the field of civil aviation.

\section{International Civil Aviation Organization - ICAO}

The international civil aviation organizations and associations include various forms of gathering and joint action of different countries or other legal entities, in order to achieve certain common objectives in the field of civil aviation. Among prominent, related particularly with the AVSEC, are:

- ICAO - International Civil Aviation Organization for Civil Air Transport,

- IATA - International Air Transport Association,

- $\quad \mathrm{ACl}$ - Airports Council International,

- ECAC - European Civil Aviation Conference,

- EUROCONTROL - European Organization for Aviation Navigation and Safety,

- EASA - European Aviation Safety Agency, etc.

\footnotetext{
${ }^{158}$ www.icao.int/Meetings/SIAS/Documents/New\%20Presentations/To\%20add\%20new/ Vladimir\%20Chertok\%20(1).pdf
} 
This paper generally is referring the ICAO, as the most important international organization in the area of the regulation of the civil aviation all over the world. As a part of UN, ICAO is established by the Convention on International Civil Aviation, signed at Chicago on 7 December 1944 and become effective from 1947. ${ }^{159}$ The headquarters of ICAO are in Montreal, Canada. The basic aim of ICAO is to provide the international civil aviation to develop into a reliable, safe, regular and efficient manner in cooperation with all its Member States, based on the principle of uniformity and equality of all involved subjects, as a part of global transportation system. Currently it's comprised of 190 countries.

The main objectives of ICAO are: developing the basic principles and techniques in international aviation and promotion of international air transportation, preventing any kind of discrimination in international civil aviation, improving the aviation safety, encourage the development of airways, providing balanced development of the aviation all over the world, preventing unfair competition between ICAO Member States, adopting standards and recommendations in all areas of civil aviation, encourage the development of airports and aircraft, care for equal opportunities for all Member States in the maintenance of international airways and much more.

ICAO has three basic functions, such as: administrative, legislative and judicial. The most important ICAO bodies are: the Parliament, the Council, the Secretariat and the General Secretary. The required common rules and provisions are issued through regular and periodical publications, in the form of standards or recommendations, contained in annexes and manuals. ICAO Member States bound to implement and apply these provisions through their own national legislation. ${ }^{160}$ The most important legislative role of ICAO is the formulation and adoption of the SARPs for the international civil aviation. The SARPs for the international civil AVSEC were first adopted by the ICAO Council in March 1974 and designated as ICAO Annex 17 to the Chicago Convention. ICAO Annex 17 was adopted in six languages - Arabic, Chinese, English, French, Russian and Spanish. ${ }^{161}$ ICAO Annex 17 process the international SARPs for AVSEC, regarding the protection of civil aviation against the acts of unlawful interference. Thus, the primary targeting of each contracting state is the safety of the

\footnotetext{
${ }^{159}$ http://www.icao.int/Pages/default.aspx

${ }^{160}$ T. Tuntev - Aerodromes - Faculty of Technical Sciences Bitola 2005

${ }^{161}$ http://www.icao.int/Security/SFP/Pages/Annex17.aspx
} 
passengers, crew, staff and the public, in matters related to the protection of the civil aviation against unlawful acts. Contracting states shall establish and implement the regulations, practices and procedures to protect the civil aviation against all kind of illegal acts, taking into account the safety, regularity and efficiency of flights, and will ensure that such organization, regulations, practices and procedures will protect the safety of passengers, crews, ground staff and the general public, in matters related to the provision of be able to respond quickly to increased security threats. ${ }^{162}$

The Aviation Security Policy (ASP) Section of the ICAO Aviation Security and Facilitation Office is responsible for the development of new and amended Standards and Recommended Practices (SARPs) for the security of international air transport. This is promulgated in the technical annex to the Chicago Convention, specifically Annex 17 - Security.

Among other things, the ASP Section manages its programs by:

- developing and updating Annex 17 to the Convention on International Civil Aviation (also known as the Chicago Convention);

- managing and overseeing the work program of the Aviation Security (AVSEC) Panel as well as its working groups;

- $\quad$ updating and maintaining the ICAO Security Manual for Safeguarding Civil Aviation Against Acts of Unlawful Interference (Doc 8973);

- maintaining the Technical Annex to the Convention on the Marking of Plastic Explosives for the Purpose of Detection;

- providing support to the International Explosives Technical Commission (IETC);

- promoting implementation of security-related SARPs;

- Providing support to various governing entities at ICA0, in particular the Assembly, Council and Committee on Unlawful Interference (UIC). ${ }^{163}$

The ASP Section is also responsible for fostering cooperation on security matters with other United Nations agencies and international bodies. Among the many entities with which the ASP Section coordinates its work are the UN Counter Terrorism Committee (UN CTC), Counter-Terrorism Committee Executive Directorate (CTED),

\footnotetext{
${ }^{162}$ ICAO - Анекс 17 International Standards and Recommended practices.

${ }^{163}$ http://www.icao.int/Security/SFP/Pages/default.aspx
} 
International Air Transport Association (IATA) and Airports Council International (ACl). ${ }^{164}$

ICAO Security Manual (Doc 8973 - Confidential) is a guidance how to apply and implement the SARPs related to the AVSEC. ICAO Annex 17 and ICAO Doc 8973 are constantly reviewed and amended on the basis of new threats and technological developments that have an impact on the efficiency of measures designed to prevent acts of unlawful interference. New and updated guidelines are often published, as a result of the unpredictability of the acts of unlawful interference, different ways of behavior, new landside security aids, new screening and surveillance methods, etc. ICAO Doc 8973 is available on few languages: Arabic, Chinese, English, French, Russian and Spanish. ${ }^{165}$

Reporting and sharing information among ICAO Member States about the acts of unlawful interference have great importance for the establishing an efficient global security policy. That gives to ICAO the necessary data that are crucial for the evaluation and analysis of different security incidents, events and trends. In accordance with ICAO Annex 17, each contracting state must provide relevant information for each incident of unlawful interference, so that by analyzing these events, the experts develop effective measures and procedures for AVSEC.

ICAO is providing an efficient AVSEC strategic goals, through coordinated activities:

- Initiatives to develop policies and SARPs,

- Monitoring of the main trends and indicators in the field of security,

- Analysis of the security,

- Implementing appropriate programs and plans to solve some safety related issues. $^{166}$

\footnotetext{
164 Ibid.

165 http://www.icao.int/Security/SFP/Pages/SecurityManual.aspx

${ }^{166} \mathrm{http}$ ///www.icao.int/safety/Documents/ICAO_State-of-Global-Safety_web_RU.pdf
} 


\section{Civil AVSEC in Macedonia and other Balkan's countries}

As a member of UN from 1993, Republic of Macedonia is a member of ICAO from 9 October 1993 and member of ECAC from 3 July 1997. That means Republic of Macedonia is obliged to respect, apply and implement all international SARPs related to the AVSEC into the national legislation.

According to the national Act of law on Aviation, the safety and security issues and structures in the aviation field are organized through:

- Ministry of Transportation and Communications,

- Civil Aviation Agency (CAA),

- Ministry of Interior affairs (Police),

- Airport operators,

- Airlines,

- Macedonian Navigation (M-NAV) ATMS. ${ }^{167}$

An efficient AVSEC system on the national level can be achieved through the development, implementation and maintenance of comprehensive flexible and effective legislation, programs, measures and procedures nationwide. The guidelines for the development of the national AVSEC should always be in line with the relevant international regulations.

The AVSEC organizational structure in all Balkan states is more or less very similar. There are some particular differences about the level of implementation of the international SARPs, as well as the level of technical development, modernity, features and capabilities of the AVSEC equipment and aids. For example, in Serbia there is a big number of adequate and appropriate AVSEC programs and plans for training and quality control; also, there is an efficient inspection system for continuously and detailed monitoring and applying AVSEC measures and procedures, based on international SARPs. The AVSEC national legislation of Croatia, as a member of EU, is fully in accordance with the European legislation and all other relevant international SARPs. The security measures, applied by the subjects involved in the national aviation, are controlled by the national CAA, as a state body in charge in the area of civil AVSEC. In Slovenia the situation is the same as in Croatia.

167 Закон за воздухопловство Сл. весник на Р.Македонија бр.63 од 13.05 .2013 


\section{Securiagues}

In Montenegro there is a Security department within the national CAA, responsible for implementing the international SARPs related to the AVSEC, supervision of the efficiency of the involved entities against acts of unlawful interference, adoption of regulations, programs and procedures, coordination with the other relevant authorities, etc.

\section{Development and application of an advanced AVSEC equipment}

The new technologies, implemented in highly developed countries in the world, certainly need to be an objective for all other countries to implement them according theirs possibilities. The efficient and modern AVSEC equipment and devices should be use at all international airports worldwide, including Balkan countries. This need is continuing and sometimes inevitable when it comes as the urgent and unquestionable obligation, regarding the applicability of modern devices, for the detection of explosives, security scan of the whole body of the passengers, etc. In terms of equipment and devices used in the function of the security, it is necessary to meet the needs and requirements about the compatibility of the specifications required in domestic and international regulations.

The modern technology undoubtedly contributes to the development of very sophisticated new models and types of security devices. That means certain illicit substances or dangerous objects, which could disrupt the safety, should be more easily determined and found. As an explicit example for every day development, upgrading and modernization is the X-ray technology, as well as the latest modern devices for detection of explosives, narcotics, weapons and other prohibited items and substances. Such devices, offering a wide range of systems with various dimensions and performances, are very useful and aimed, for instance, to analyze fluid going through and to determine its chemical composition, in order to determine whether it's a threat or not. Furthermore, developing CT (computed tomography) technology allows 3D images and high resolution. ${ }^{168}$ These new detectors for passengers scanning allowed seeing the image of the body and even the detection of the smallest objects possessed by the person that could be a threat. At last but not at least, the positive personal

${ }^{168}$ http://www.x-rayscreener.co.uk/x-ray/\#other-tech 


\section{Securiagues}

identification via biometric models allowed to confirm with $100 \%$ certainty the identity of the person trying to access to certain restricted areas. The biometrics refers to the parameters associated with the human characteristics. ${ }^{169}$

It's also necessary to mention that the "digital security" is in the top 10 trends in AVSEC equipment development; this new modern technology is used to develop an advanced security concept, such as "walk though security"; it helps to reduce the waiting time and increase the flow of passengers; also it's enabling automated verification, reduction of the security staff and increased level of the security. ${ }^{170}$ The great progress of the new technologies and the training processes of the security staff certainly contribute to improve the physical and psychological effects that every modern security system should achieve. The fast development and modernization of the AVSEC equipment and devices are motive and incentive to all other areas related to the security of any other kind of the "critical infrastructure". Not just the airports and aircraft, but also all other objects of "critical infrastructure" are becoming an objective of new security measures and procedures, such as train stations, bus stations, hydropowers, thermal powers, nuclear power plants, water supply plants, factories, government facilities, etc. The use of the new security equipment and devices must keep pace with the implementation of the relevant and appropriate legislation that comes primarily from validated universal SARPs. That's should be an imperative for further and continuous development, implementation, coordination, control and improvement of the security, not just in a field of civil aviation, but also in any other area with needs to secure the "critical infrastructure".

\section{Conclusion}

The global aim in the world of civil aviation is achieving the unified level of aviation safety and security all over the different countries and continents. Therefore, each government, through its CAA as state body in charge of national aviation safety and security, adopts a comprehensive state policy, followed by appropriate legislation

\footnotetext{
${ }^{169}$ https://www.google.com/webhp? sourceid=chromeinstant\&ion=1\&espv=2\&ie=UTF8\#q= biometric+security+tehnology.

170 https://www.aviation-insider.com/resource/top-10-trends-aviation/
} 


\section{Seccurity}

implemented by all entities involved in any security structure within the national aviation transport system. According SARPs in ICA0, Annex 17 is the main sources and guidelines for establishing an official state policy in the field of each particular national AVSEC system.

The national and international security, including AVSEC as a part, is a complex and extensive system, as an interdependent set of legislations, measures, plans, activities, technologies and programs that must be well coordinated. Therefore, the efficient and appropriate security policy would mean constantly contribution to maintaining and improving the security in all areas, especially in aviation. Hence, the security policy should be directed to the extension of the existing regulations and practices; it should be aimed at identification and defining the feasibilities, possibilities and conditions for applying of advanced practices, procedures and systems and their implementation in the development of each national security system. The practical applicability of certain standards and procedures, arising from the final operationalization of the proposed solutions, should be a priority for every country.

Every day all over the world there are larger and more dangerous threats posed by globalization. That's require a new approach to the security organization and facilities. An efficient security protection must be effective 24 hours a day, with the inclusion of advanced security systems that follow new and modern technological advances. Security systems are in constant development, in order to meet the requirements arising from the practice. The implementation of new and modern security systems and devices depends on several factors, but the most significant thing is that the investing in security equipment and devices should be permanent. No doubt that the equipping of the security services in accordance with modern achievements in this area includes the possibility for smooth and efficient execution of the given tasks, corresponding to the risks and dangers of the modern times.

The civil aviation is one of the most regulated areas on both levels international and national. That could be a real example for all other areas of activities in the countries, especially for those with great and significant importance for the government and public. That's why there is a need of cooperation, coordination and legislative compliance not just for civil aviation, but also for all other fields that contains objects of "critical infrastructure". The modern security challenges and their impact on the vital state infrastructure - "critical infrastructure", are presented through the vulnerability and fragility of the national security, national economy, national health 


\section{Seccurity}

system, as well as the efficient functioning of the government institutions and bodies. That's why the proper and adequate implementation of the relevant and approved international security measures and procedures should be a real challenge for establishing a comprehensive national security policy. This must be followed by proper national legislation and implementation of modern security systems and procedures in developing the efficient security of "critical infrastructure". So, the national AVSEC system should be a base, guideline and real example for every country in the future, to provide an efficient and comprehensive "critical infrastructure" security system.

\section{References:}

1. T. Tuntev - Aerodromes - Faculty of Technical Sciences Bitola 2005.

2. Protection for critical infrastructure: Oliver Bacreski, Tanja Milosevska, Gjorgji Alceski - Skopje 2017.

3. ICAO - Annex 17 International Standards and Recommended practices.

4. ECAC (European Civil Aviation Conference) - Doc 30,

5. EU regulatives, https://www.iaa.ie/docs/default-source/publications/aviationsecurity-legislation/ec-regulation

6. Закон за воздухопловство Сл. весник на Р.Македонија бр.63 од 13.05.2013

7. http://www.x-rayscreener.co.uk/x-ray/\# other-tech

8. https://www.google.com/webhp? sourceid=chromeinstant\&ion=1\&espv=2\&ie=UTF $8 \# q=$ biometric +security+tehnology.

9. https://www.aviation-insider.com/resource/top-10-trends-aviation/

10. http://www.icao.int/Security/SFP/Pages/SecurityManual.aspx

11. http://www.icao.int/safety/Documents/ICAO State-of-Global-Safety web RU.pdf

12. http://digitool.library.mcgill.ca/webclient/StreamGate?folder id=0\&dvs=14909672 83946-457

13. http://www.icao.int/Meetings/SIAS/Documents/New\%20Presentations/To\%20add \%20new/Vladimir\%20Chertok\%20(1).pdf

14. https://www.ecac-ceac.org/about-ecac

15. http://www.caa.gov.mk/86/Chlenstvo vo megjunarodni organizacii.html

16. http://www.bbc.com/news/world-europe-12268662

17. http://www.aljazeera.com/news/europe/2013/02/20132515350158754.html 
18. http://edition.cnn.com/2015/10/31/middleeast/egypt-plane-crash/

19. http://www.reuters.com/article/us-turkey-airport-blastidUSKBNOU60DS20151223

20. http://www.bbc.com/news/world-europe-35869985

21. https://www.rt.com/news/348735-explosion-atatukr-reports-injured/

22. http://edition.cnn.com/2013/09/26/world/pan-am-flight-103-fast-facts/

23. http://www.bbc.co.uk/history/events/the september 11th terrorist attacks 